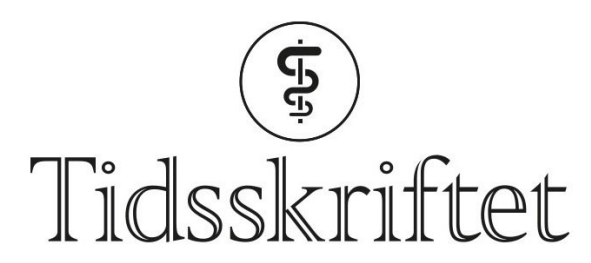

DEN NORSKE LEGEFORENING

\title{
Turnus og Æneas
}

MINILEDER

\section{ARE BREAN}

Sjefredaktør

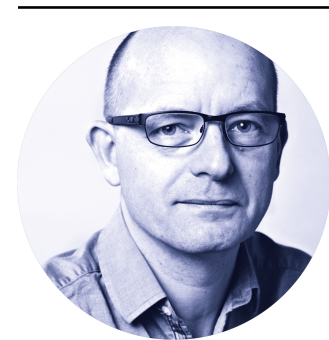

Turnustjeneste for leger ble innført i 1953. Formålet var å bygge bro mellom et overveiende teoretisk studium og den praktiske, kliniske hverdagen som lege. Etter 63 år er det slutt. De aller siste turnuslegene avslutter sin tjeneste i disse dager. Leger i spesialisering del 1 (LIS1) er det nye, men kanskje ikke så velklingende, navnet på det som inntil nå har vært turnustjeneste.

For leger i spesialisering del 1 gjelder, som før, krav om ett år på sykehus og et halvt år i kommunehelsetjenesten. Deretter går spesialistkandidatene enten til del 2 (LIS2) eller direkte til del 3 (LIS3), avhengig av spesialitet. Selv om nyordningen ønskes velkommen av de fleste, er det fortsatt bekymring knyttet til den. Blant annet blir minste utdanningstid forkortet, og det er usikkerhet rundt kurs- og prosedyrekrav og hvordan læringsmålene skal innfris.

Turnus var i romersk mytologi konge over rutulerne. Han var en seiersrik kriger inntil han ble drept i kamp med Æneas - som gudene senere gjorde udødelig. Det gjenstår å se om den nye ordningen varer lenger enn turnusordningen har gjort. Men udødelig blir den neppe.

Publisert: 4. september 2017. Tidsskr Nor Legeforen. DOI: 10.4045/tidsskr.17.16.01 (C) Tidsskrift for Den norske legeforening 2020. Lastet ned fra tidsskriftet.no 